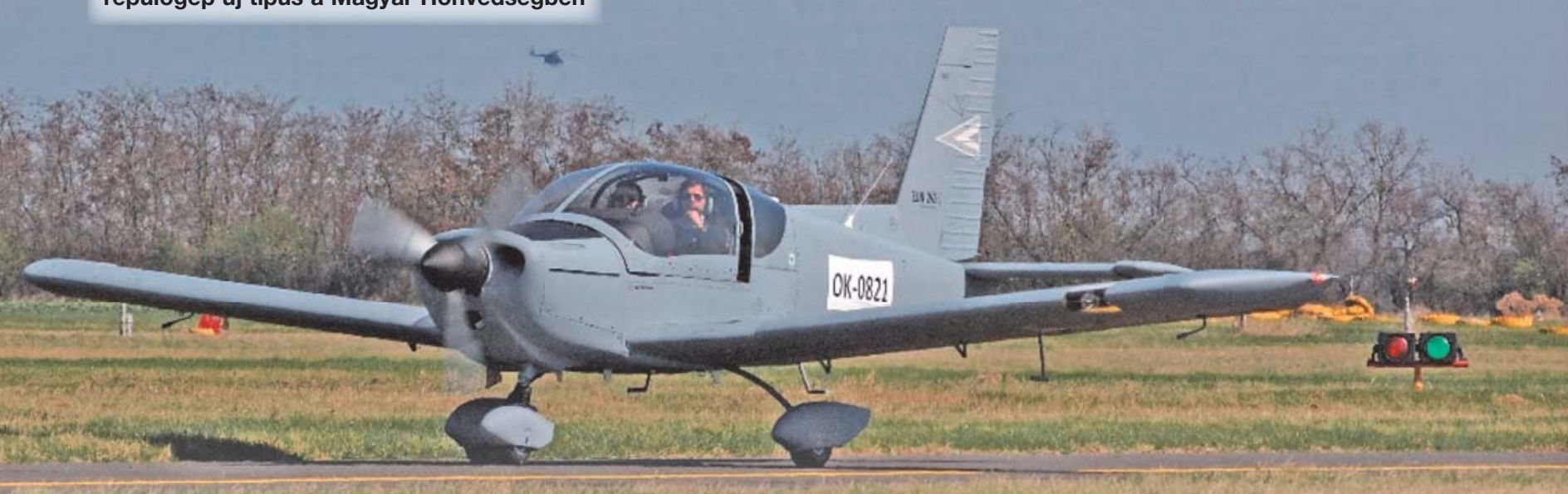

Hennel Sándor* - Kelecsényi István

\title{
Kiképző repülőgépek a Magyar Honvédségnél - a Jak-52-estől a Zlin gépcsaládig, kitekintéssel a jövő lehetőségeire
}

2

017. március 24-én újabb típussal gyarapodott a Magyar Honvédség légiereje. Kettő darab kétüléses Zlin Z-242L típusú kiképző repülőgép érkezett Csehországból az MH 86. Szolnok Helikopter Bázisra. A repülőgépeket egy Zlin Z 143 LSi típusú repülőgépen a Zlin Aircraft a.s. Repülőgépgyár igazgatója kísérte el. Az otrokovicei gyárban kettő darab négyüléses Zlin Z-143LSi is készül magyar megrendelésre, és dr. Simicskó István honvédelmi miniszter a bázison tartott beszédében második ütemben további 2-2 repülőgép beszerzését ígérte. [2]

\section{A JAK-52-ES KIKÉPZŐ REPÜLÖGÉP}

A Zlin repülőgépek a Jak-52-es képző repülőgépek váltótípusai, amelyekből 1993-ban érkezett 12 darab Szolnokra, így ismételten elindulhatott a repülőhajózó képzés hazánkban.

A Jak-52-est a Jak-50-es repülőgép alapján fejlesztették a Szovjetunióban, de gyártását 1977-től a romániai Aerostar S.A. Bacau repülőgépgyár végezte. Romániában napjainkban is folyik a gyártás, de már a modernizált

ÖSSZEFOGLALÁS: A cikk ismerteti a Jak-52-es kiképző repülőgép hazai katonai alkalmazásának történetét, illetve - a 2017-ben beszerzett Zlin kiképző repülőgépekhez kötődően - a különféle Zlin könnyű repülőgépek hazai alkalmazásának történetét is. Kitekintésképpen - egy jelenleg készülő doktori értekezés anyagából merítve - elemzi a hazai ipar lehetőségeit egy többfeladatú, kettős felhasználású katonai könnyű repülőgép típus előállitása területén.

KULCSSZAVAK: kiképző repülőgép, Jak-52, Jak-152, Zlin Z-242L, Zlin Z-143LSi, Magyar Honvédség

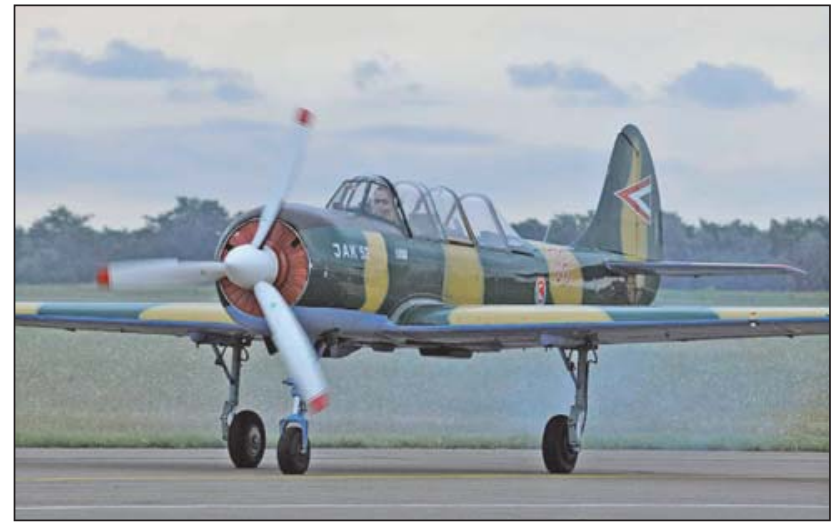

2. ábra. A Zlin-ek a korábbi Jak-52-es kiképzörepülögép-típust váltották le a Magyar Honvédségnél

Jak-52W változattal. 1994-ben a ládákban hazánkba szállított Jak-52-eseket Szolnokon a bázis műszaki állománya és a román gyár szakemberei közösen szerelték össze,

ABSTRACT: This article deals with history of Hungarian application of the Yak-52 trainer aircraft, and of the several types of the Zlin light aircraft procured for pilot training in 2017. Taking from a PhD thesis being in preparation, it analyses possibilities of the Hungarian industry in manufacturing a multirole dual-use light military aircraft.

KEY WORDS: trainer aircraft, Yak-52, Yak-152, Zlin Z-242L, Zlin Z-143LSi, Hungarian Defence Forces

\footnotetext{
Okleveles mérnök őrnagy, helikopter- és repülőgép-hajózó. A Nemzeti Közszolgálati Egyetem Katonai Műszaki Doktori Iskolájának doktorjelöltje.
} 


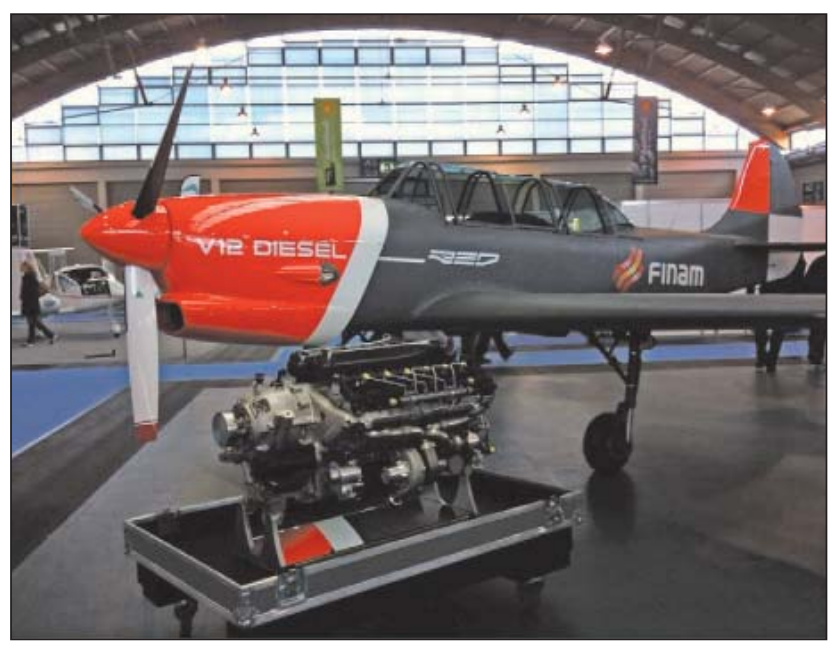

3. ábra. Audi eredetü Raiklin RED-3 típusú, 500 LE-s repülőgép-dízelmotor egy korszerúsített Jak-52-es kiképző repülőgépben

majd először a Szolnoki Repülő-Műszaki Főiskola, majd később a bázis alárendeltségébe tartozó kiképző század állományába kerültek. A 12 darab repülőgépből jelenleg 10 darab van a bázison, a 04-es oldalszámú gépet a szolnoki repülőmúzeumban, a Reptárban állították ki.

A 08-as oldalszámú Jak-52-es 2003. november 12-én Tiszagyenda határában lezuhant, és mindkét nagy tapasztalatú pilótája Lanecker József ezredes és Szász Gábor őrnagy életét vesztette. 2015. június 25-én a szolnoki bázis körzetében gyulladt ki egy másik Jak, amelynek hajózói Litauszky Zoltán alezredes és Horváth László őrnagy kényszerleszállást hajtottak végre. A baleset után a honvédség a típust leálította. Más országokban sor került a típus korszerűsítésére, amelynek egyik fő folyamata az elavult, tűzveszélyes karburátoros Otto-motor lecserélése volt korszerü, kerozinnal is üzemeltethető dízelmotorra.

Az orosz Jak (Irkut) tervezőintézet 2017-ben mutatta be az utódváltozatot, a Jak-152-es alapfokú kiképző repülő- gépet, amelybe egy RED A03 típusú, 373 kW (500 LE) maximális teljesítményű, V12 henger-elrendezésű dízelmotort építettek be.

\section{A JELEN: A ZLIN KIKÉPZŐ REPÜLŐGÉPEK}

A kanadai NFTC (NATO Flying Training in Canada) NATO pilótakiképzéshez szükség volt Magyarországon a kiválasztáshoz alapfokú kiképző repülőgépre. Ezt a Zlin cég kölcsön Z-143 OK-TUT lajstromú repülőgépével végezték Szolnokon. 2016. január 19-én a HM Beszerzési Hivatala közbeszerzéssel ajánlatot kért a Jak-52-esek felváltására, kettő darab ICAO „A” kategóriás kiképző, és kettő darab négyszemélyes könnyű felderítő és futárgép szállítására. A nyertesnek 4 fő hajózó és 10 fő műszaki kiképzését is vállalnia kellett fél év alatt. 2016. augusztus 11-én a cseh Zlin a.s. nyerte el a tendert.

A Zlin gyártmányú repülőgépeknek lassan egy évszázados története van a magyar repülés történelmében. A II. világháború előtt már repültek Zlin XII-esek Magyarországon. A műrepülhető, egymás mögötti kétüléses repülőgépet magáncélú repülésre és kiképzésre is használták.

A II. világháború alatt a Cseh - Morva Protektorátusban német ellenőrzés alatt tevékenykedett a Zlin cég és a Bücker 181 Bestman típust gyártotta. A háborús években ezt a típust is használta a Magyar Királyi Honvéd Légierő és a repülő kiképzésért felelős HMNRA. A repülőgépeket nem közvetlenül a cseh gyártótól, hanem német közvetítéssel kaptuk, a német repülésügyi minisztériumon keresztül. (Így dokumentumokkal nem igazolható pontosan, nem ellenőrizhető, hogy mekkora mennyiségben és milyen gyártótól érkeztek ezek a repülőgépek).

A háború után a Z-281 és 381 típusokat alkalmazták hazánkban, amelyek lényegében a Bestman csehszlovák, Zlin által továbbra is gyártásban tartott változatának tekinthetők.

Hazánkban a háború után - az UT-2 típus kivételével - a katonai hajózó-alapképzés végig Zlineken folyt. Általában 3600 óra volt a Zlinek élettartama. A képzés során évi 3-400 órát repültek.

4. ábra. A Jak-52-es utóda, a Jak-152-es alapfokú kiképző repülőgép, amelyet egy RED A03 típusú, 500 LE teljesítményű, V12 henger-elrendezésǔ dízelmotorral szereltek fel

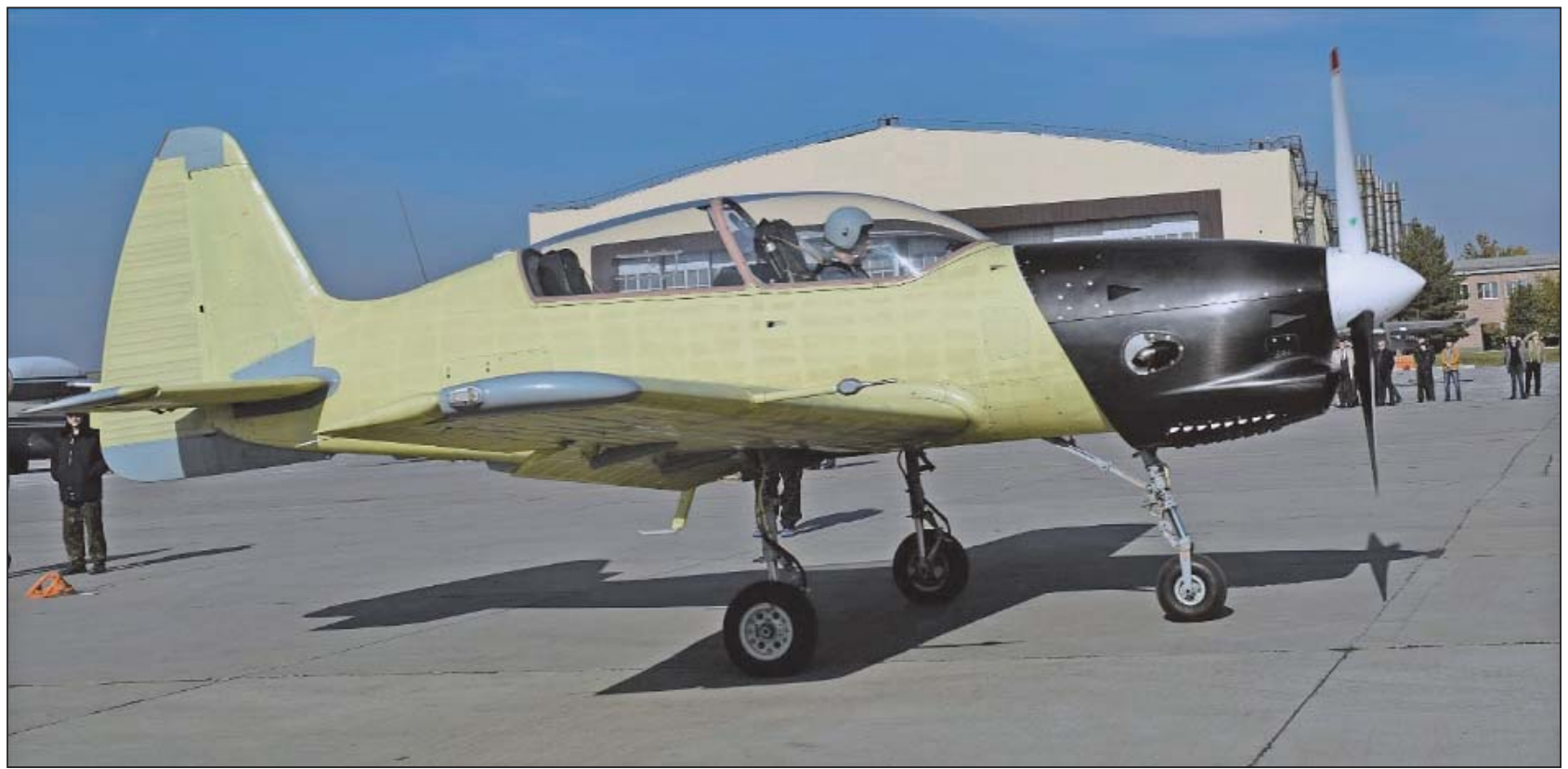




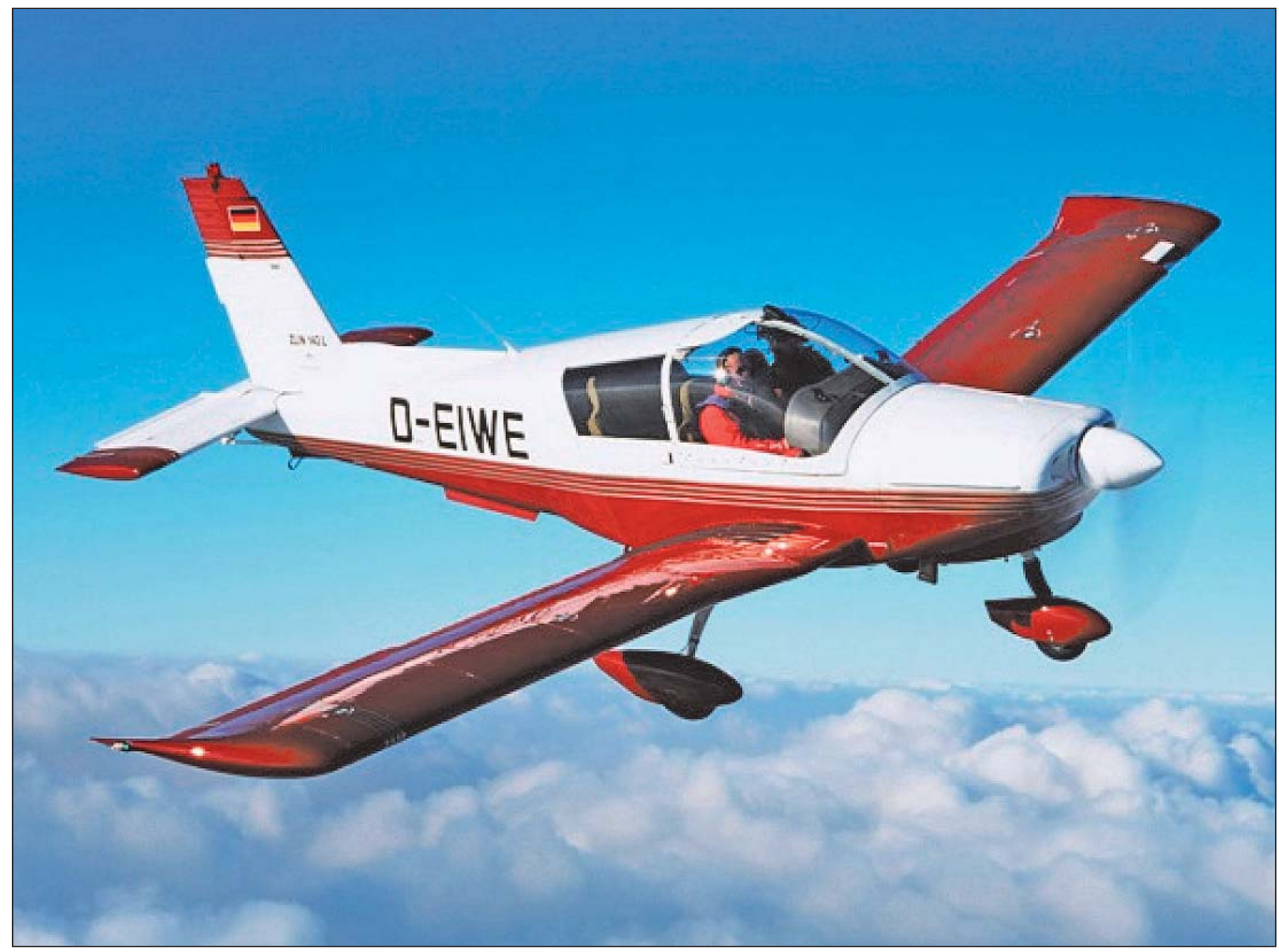

5. ábra. A négyüléses Zlin Z-143LSi „Genius” könnyű repülőgép

Zlin repülőgépek a II. világháború után, 1948. óta repültek a magyar haderő állományában. Ekkor 25 darab, Zlin 381-es „Fecske” érkezett kiképzőgépnek hazánkba, majd 1949-ben újabb 25 darabot vásároltunk. A Fecskéket a nagyközönség számára 1950. április 4-én tartott díszszemlén mutatták be. A gépek hosszú ideig szolgálták a kiképzést, majd kiselejtezték őket.

A Magyar Honvédelmi Szövetség, az MHSZ a későbbi katonai pilóták kiképzésére 1960-ban vette át az első Z-226T oktató repülőgépet. A HA-TRA lajstromú repülőgépet 1958-ban gyártották, használtan szerezték be. 1960ban újabb hét 226-os „Tréner” beszerzése realizálódott, majd 1961-ben a Z-326-os modernizált változatából vásároltak három darabot. Ez a beszerzés jelentős löketet adott a versenysportnak is. 1962-ben a budaörsi II. Motoros Műrepülő Világbajnokságon szabadon választott kategóriában Katona Sándor, valamint a műrepülő válogatott (Katona Sándor, Fejér Miklós, Fejes Péter, Pál Zoltán, Tóth József) is aranyérmet szerzett. A Magyar Repülő Szövetség később újabb három $226 T$ és kilenc Z-326-ost vásárolt. A repülőgépek a Zlin 142-esek beszerzéséig az alapfokú kiképzés fő repülőgép típusai lettek. 1967-ben egy Z-526-os és három Z-526A változatú „Tréner Master” érkezett az MHSZ-hez, majd T-526F változatokat szereztek be. Verseny-repülőgépnek kettő T-526AFS is érkezett. A kiöregedett Z-326-osok pótlására hét darab Z-726-os került hazánkba.

1968-ban a nyíregyházi repülőiskola részére (hivatalosan RNA - Repülőgépes Növényvédő Állomás) 6 db Z-526-os repülőgépet vásároltak, majd további 3 db Z-526 F-et, ezek már benzin-befecskendezéses motorral készültek. A repülőiskola részére további $2+3 \mathrm{db}$ Zlint vásároltak. Az 1970-es évek végén 6 db Z-42 M-et vásároltak a MÉM RSZ, a repülőgépes szolgálat számára. Később további 5 db Z-142-es gépet kapott a MÉM Repülőgépes Szolgálata. Az 1981 végén érkezett 3 db Z-50LA típusú, MÉM RSZ tulajdonú Zlin repülőgéppel Makláron folyt a kiképzés az 1982-es osztrák világbajnokságra készülve. 1983-tól az MHSZ is vett $4 \mathrm{db}$ Z-50 LS típusú repülőgépet.

Időközben a Zlin cég kapta meg gyártásra a Čmelákot, amit korábban a Kunoviczei Let cég gyártott. A Zlin fejlesztette ki a Turbo Čmelákot. Hazánkba került ennek a repülőgépnek a prototípusa is. Később az 1990-es években megjelent a Z-37 T szériagyártású repülőgép a magáncégeknél. A Z-137 T-t már jelentősen megnövelt sárkányszerkezet-mérettel bocsátották ki, a gázturbina teljesítményét vissza kellett szabályozni. (Ezt úgy oldották meg, hogy a gázturbina gázgenerátor részéről egy hajtást vezettek el a növényvédőszer-tartályhoz, amely a granulátum keverését biztosította.) A nagyteljesítményű gázturbinás típus a dugattyús motorhoz képest közel kétszeres fogyasztással bírt. Ennél a típusnál a törzset egy méterrel meghosszabbították, terhelhetősége pedig egy tonnára növekedett.

1976-ban a Technika Külkereskedelmi Vállalat 6 db Z-43-as típusú repülőgépet szerzett be. Ezek közül egy - a BM Rendőrség repülőgépe - 1976. júniusban egy R-01-es oldalszámú Z-43-assal, Siófok mellett a Balatonba zuhant. Egy darabot az MHSZ kapott. A 075-081-es oldalszámú 
repülőgépek (4 db) 2002-ig repültek a honvédségnél, majd polgári értékesítésre kerültek. A 078-as oldalszámú repülőgép a Keceli haditechnikai gyűjteményben található.

Megemlítendő továbbá, hogy az L-29-es Delfin és az L-39-es Albatrosz repülőgépekhez a futó kerekeket és a fékeket, továbbá a farokfelületeket és a kormánylapokat, illetve a katapultüléseket is a Zlin cég gyártotta.

Megjegyzendő, hogy a Zlin gyár a polgári életben is sikerrel szerepelt hazánkban, a MÉM Repülőgépes Szolgálata 1979-ben szerzett be hat darab Zlin Z-42M repülőgépet, amely a legsikeresebb Zlin típusok közé tartozott.

Az Aerotriga nevű műrepülő formáció elődje, Z-526Fekkel, a nyíregyházi főiskolán alakult meg 1973-ban.

A későbbiekben, amíg a MÉM RSZ müködött, addig finanszírozták a Z-50LA mürepülő-gépeket. Amikor a MÉM RSZ felbomlott, a repülőgépeket eladták külföldre. Az MHSZ Zlinjeit a Magyar Repülő Szövetség örökölte, amelytől az Aerotriga bérelte a MALÉV közreműködésével. Az Aerotriga megszűnésével a gépeket eladták.

A most beszerzett kétüléses Zlin-242L „Guru”-t polgári, vagy katonai oktatógépnek tervezték. A fülkéje a modern kor kihívásainak megfelelően félig képernyős (Glass Cockpit), félig hagyományos műszerezettségü. Motorja amerikai gyártmányú Textron Lycoming AEIO-360-A1B6os, amely 150 kW-os (200 LE-s), és egy német gyártmányú háromtollú kompozit légcsavart hajt meg. Az alsószárnyas fémépítésű merev futóműves Guru hosszúsága 7,0 m, szárnyainak a fesztávolsága 9,3 m, teljes magassága $3 \mathrm{~m}$, +6 és -3,5 G között műrepülhető. Maximális felszállótömege 1090 kg (mürepülő feladat esetén 970 kg) a szerkezeti tömege pedig $745 \mathrm{~kg}$ a repülőgépnek. Két darab 60 literes üzemanyagtartály mellett, két darab 55 literes póttartállyal is felszerelhető. Az alap tartályokkal 2000 méteres magasságban gazdaságos repülési sebességgel, a gyári adatok szerinti hatótáv eléri a 495 km-t. Teljes terheléssel 266 méteres pálya szükséges a felszálláshoz.

A négyüléses Z-143LSi „Genius” hasonló kialakítású, mint a „Guru”. Üres tömege 110 kg-mal, szárnyfesztávolsága $0,5 \mathrm{~m}$-rel több, mint a kétüléses testvértípusé. Maximális felszállótömege 1350 kg, egyéb méretei csak minimálisan térnek el. A motorja a Textron Lycoming IO-540C4D5-ös, ami 175 kW-os (235 LE-s), amely a 242L-nél, és karburátorral, injektorral, turbóval is rendelhető, így akár a 260 kW (350 LE) is elérhető. A légcsavarja kompozitból készült háromtollú, MTV-9-B/195-45-ös típus. A Z-143LSi típus is műrepülhető, de szerényebb +4,4 -1,76 G túlterheléssel. Gyári adatok szerint 3000 m-en 243 km/h-s sebességgel $1100 \mathrm{~km}$ a hatótávolsága, két beépített 60 literes üzemanyagtartállyal, amelyet növelni lehet két 51 literes póttartállyal. Felszállásához némileg nagyobb, 300 méteres úthossz szükséges.

A Z-143LSi futár, kiképző feladatokon kívül, a géptörzs alá szerelhető UltraForce 275 gyártmányú kamerarendszerrel felderítő repülőgépként is használható. A kamerák között 0,5 lux minimális fényigényű HD felbontású nappali és 2-5 mikron hullámhosszban működő 640-512 képpont felbontású infravörös is rendelkezésre áll. A kamerák teljes $360^{\circ}$-ban forgatható gömbházban a négy aktív tengely mentén stabilizáltan kerülnek beépítésre. A gömbből $20^{\circ}$ ban felfelé, $-120^{\circ}$-ban lefelé lehet álítani, forgási sebessége másodpercenként $60^{\circ}$. Az érzékelőgömb tömege $15 \mathrm{~kg}$, átmérője $27,5 \mathrm{~cm}$, tehát gyakorlatilag tömege és méretei csak kis mértékben befolyásolják a repülési tulajdonságokat. A légijármű felhasználhatósága szempontjából lényeges előrelépés az ilyen irányú berendezések beépítése. A határőrizeti feladatok, a hőkamerás felkutatások, rendészeti feladatok támogatása, gépjárművek-, operatív felada- tok nyomon követése, dokumentálása, eltűntek, bajbajutottak kutatása szinte elvégezhetetlen ezen technikai eszközök megléte nélkül. Hiánypótlóként jelentkezik ez a képesség a Magyar Honvédségben és pozitív előnyeit kevéssé csorbítja a repülő hasára szerelt és a merev futóktól korlátozott kilátása. A gép a kamerarendszeren kívül rendelkezik egy AMU1 típusjelű mozgásérzékelő és megfigyelő fedélzeti-rendszerrel.

Ez a repülőgép fontosabb elemeit, rendszereit ért terheléseket figyeli, elemzi, és előre jelzi a kialakulható hibákat. Használatával 18000 repült órára is kitolható a repülőgép élettartama. (Említésre érdemes, hogy a Sri Lankán zajlott polgárháborúban a szakadár Tamil Elám Felszabadító Tigrisek gerilla hadereje néhány felfegyverzett Zlin Z-143L sportrepülőgépet is bevetett katonai és civil célpontok ellen. Erről a Haditechnika folyóirat is beszámolt 2012-ben. [7] - Szerk.)

A mexikói haditengerészet részére szállított Z-143-asokon FLIR berendezéseket helyeztek el. Ezt a típusváltozatot tengerészeti megfigyelő repülőgépként alkalmazzák, póttartálylyal 14 órát képes a levegőben maradni. Az „Ultra Force” Zlint az illegális drogkereskedelem ellen alkalmazzák.

A Zlin 242-est, illetve a 143-ast napjainkban 18 ország alkalmazza, ebből 9 katonai kiképzésre. Ezekhez csatlakozott hazánk is.

Pavel Hajla, a Zlin Aircraft cég repülésirányítója és oktatója az átadási ünnepségen ismertette a médiával a két típus főbb jellemzőit. Mint fogalmazott, alapvetően mind a 143-as, mind a 242-es kiképzőgépnek számít. A leglátványosabb különbség az, hogy a 143-as típus négyüléses és ezáltal valamivel erősebb hajtóművel rendelkezik. Emellett a 242-es alkalmas éjszakai, műszeres repülések gyakorlására is. Azt is hozzátette, hogy a pilóták általában azért szeretik ezeket a gépeket, mert felhasználásuk skálája igen széles: a kiképző- és gyakorlórepüléseken túl, műrepülésre is alkalmasak.

Az ideiglenes cseh lajtromjellel érkező első két Zlin 242L a 21-es 22-es oldalszámot kapta. A repülőgépek a Magyar Honvédség harci repülőgépeinél használt légifölény szürke színűek. Dr. Simicskó István, Magyarország honvédelmi minisztere az üdvözlő beszédében kijelentette, hogy Magyarország drágának ítéli meg az NTFC kanadai kiképzést, és 2021 után a repülőgép-vezető kiképzés nemzeti alapon fog történni. [2] Az alapfokú légcsavaros kiképző repülőgépek mellett szükséges sugárhajtású gyakorló repülőgép is, amely a Zlin és JAS-39-es „Gripen” típusok között helyezkedik el. Ezt a beszerzést a visegrádi együttmüködés keretében tervezi a kormány és a honvédség.

\section{FEJLESZTÉSI LEHETŐSÉGEK A JÖVŐBEN: TÖBBFELADATÚSÁG, FELFEGYVEREZHETŐSÉG}

A hidegháború befejeztével a világ hadikultúrája egy újabb sarokponthoz ért, megváltozott az ellenségkép és ennek megfelelően új technikai eszköz-koncepciók jelentek, jelennek meg. A szeptember 11-i terrortámadás és a 1999es NATO csúcstalálkozó óta - ahol már a terrorizmust, mint új ellenséget nevezték meg - új szemléletmódra és új katonai erőkre, eszközökre van szükség az új feladatok ellátásához.

Hazánk katonai feladatköre a rendszerváltással és NATO-csatlakozásunkkal jelentősen megváltozott. Új kihívások, veszélyek és fenyegetések jelentek meg a térségben és a NATO szövetségesi környezetében. Szövetségesi kötelezettségeinknek megfelelően „nem háborús” tevékenységekben is egyre fokozódó mértékben jelenünk meg, 


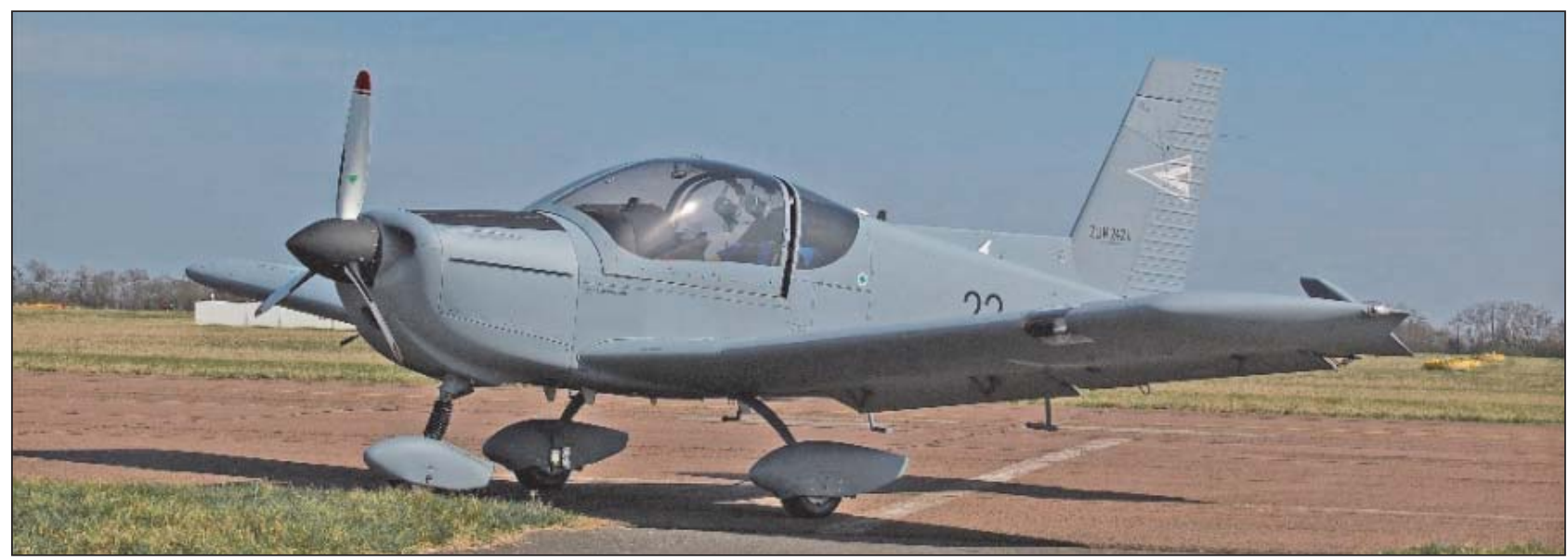

6. ábra. A Zlin kiképző repülőgép futómúve merev szerkezetű, nem behúzható

ahol a légi felderítési, a határ-megfigyelési, illetve egyéb ellenőrzési tevékenységekhez olcsóbb és kevesebb ráfordítással fenntartható eszközöket igényelnek. Ez érvényes a légierő eszközeire - köztük a kiképző- és könnyű repülőgépekre is. Az Egyesült Államokban indult LAAR program már többfeladatú, felfegyverezhető könnyű repülőgépek rendszeresítését tűzte ki célul a terrorizmus elleni harc aszimmetrikus körülményei közötti optimális alkalmazás érdekében.

A Zlin alapfokú kiképző repülőgépek, valamint a felderítő változatok a következó évtizedekben biztos alapot jelentenek a repülőgép-vezető kiképzéshez, és a felderítő változatok akár a magyar határon épült kerítés vonalában járőrözve, egyrészt idejében felderíthetik az illegálisan az államhatárt átlépni kívánó migránsokat, valamint egyéb felderítő feladatok ellátására is képesek, akár aszimmetrikus hadviselési környezetben is. A „Zrínyi 2026” programmal a Magyar Honvédség megújítására nyílik lehetőség. Felértékelődik e program keretében a magyar hadiipar szerepe is. (A szárazföldi haderő eszközei tekintetében számos eredménnyel büszkélkedhet már a magyar hadiipar: ilyen a Rába Rt. Védett-Zárt Felépítményű lövészszállító járműve, vagy a Gamma Rt. KOMONDOR védett járműcsaládja. Szerk.) A könnyű repülőgépek területén is a hazai gyártású, fejlesztésű termékek kerülhetnek előtérbe. Ezért - a tudományos kutatás keretében - érdemes előre gondolkodni, hogy a politikai, katonapolitikai és harcászati igények ho-

7. ábra. A Sri Lankán vívott gerillaháborúban alkalmazott Zlin tereptarka festéssel és $4 \mathrm{db}$ „MK-60 HE” bombával. A gép törzse alá fegyvertartóként egy rácsot erősítettek, erre függesztették fel a bombákat

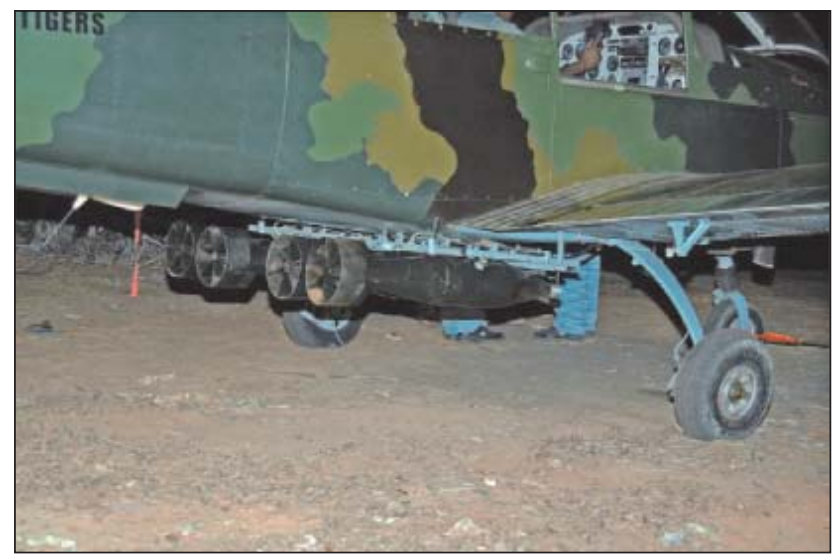

gyan változnak a következő évtizedekben és a beszerzéseket előre meghirdetett irányvonalakon lehetőséget adni a magyar iparnak a megjelent igények kielégítésére.

Jelenleg és a jövőben az új típusú repülőgépekkel szemben számos, a NATO által támasztott múszaki követelménynek kell érvényesülnie. A NATO SFC (Single Fuel Conception) - egy jelenleg érvényes, a kerozin üzemet a szárazföldi és a légi eszközök esetében a harctéren egyaránt kötelezővé tevő üzemanyag-egységesítési koncepció - nemcsak egy szövetségi rendszeren belüli elvárás, hanem számos gyakorlati kérdést is felvet egy olyan repülőtéren, ahol túlnyomó többségében gázturbinás, JET-A1 kerozin üzemeltetés folyik. [4] Számos logisztikai probléma vetődik fel, amelyek életre hívták az SFC-t. A benzinszállításhoz, a tároláshoz külön tartály szükséges, a tartályok karbantartása, fenntartása az egy helyett két külön figyelmet, ciklusidőket, dupla csővezetéket, dupla tartálykocsi parkot igényel, amelyek kezelőiből is kettőre van szükség stb. A repülőbenzin magas költsége miatt gazdaságossági szempontból nemcsak az üzemanyag ára jelent komoly megtakarítást, hanem a logisztikai rendszer egyszerúsítése is. A repülőiparban használt modern dízel meghajtású dugattyúsmotorok a dízelolaj és a kerozin vegyes üzemeltetését is lehetővé teszik. A jelentős fejlesztéseknek köszönhetően már számos gyártó állít elő olyan motorokat, amelyek a repülőiparnak és a hatóságoknak is megfelelő tanúsítvánnyal, légi alkalmassági engedéllyel rendelkeznek. Ezen

8. ábra. Hőkamerás felvétel Colombo Dockyard felett forduló Z-143L-röl, a Sri Lankán vívott gerillaháborúban. Az eleve csekély höképet motorburkolat-szigeteléssel és módosított kipufogórendszerrel csökkentették tovább

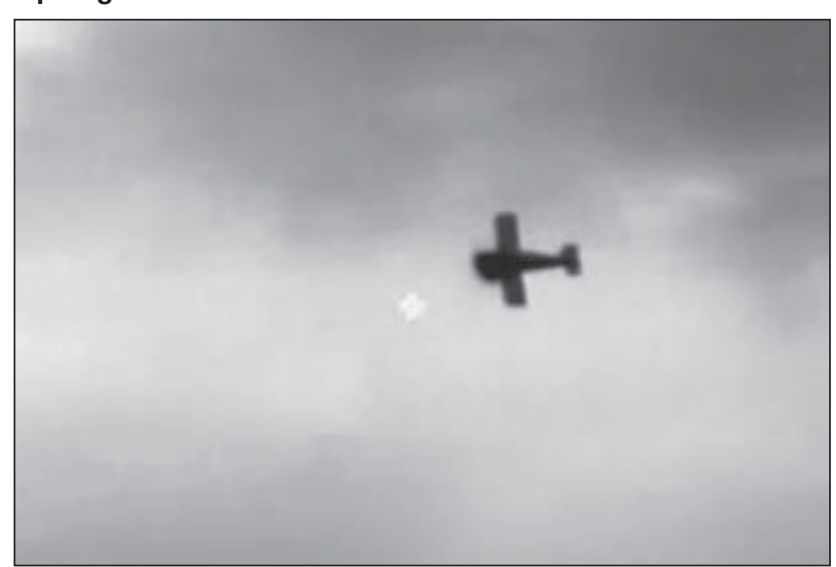




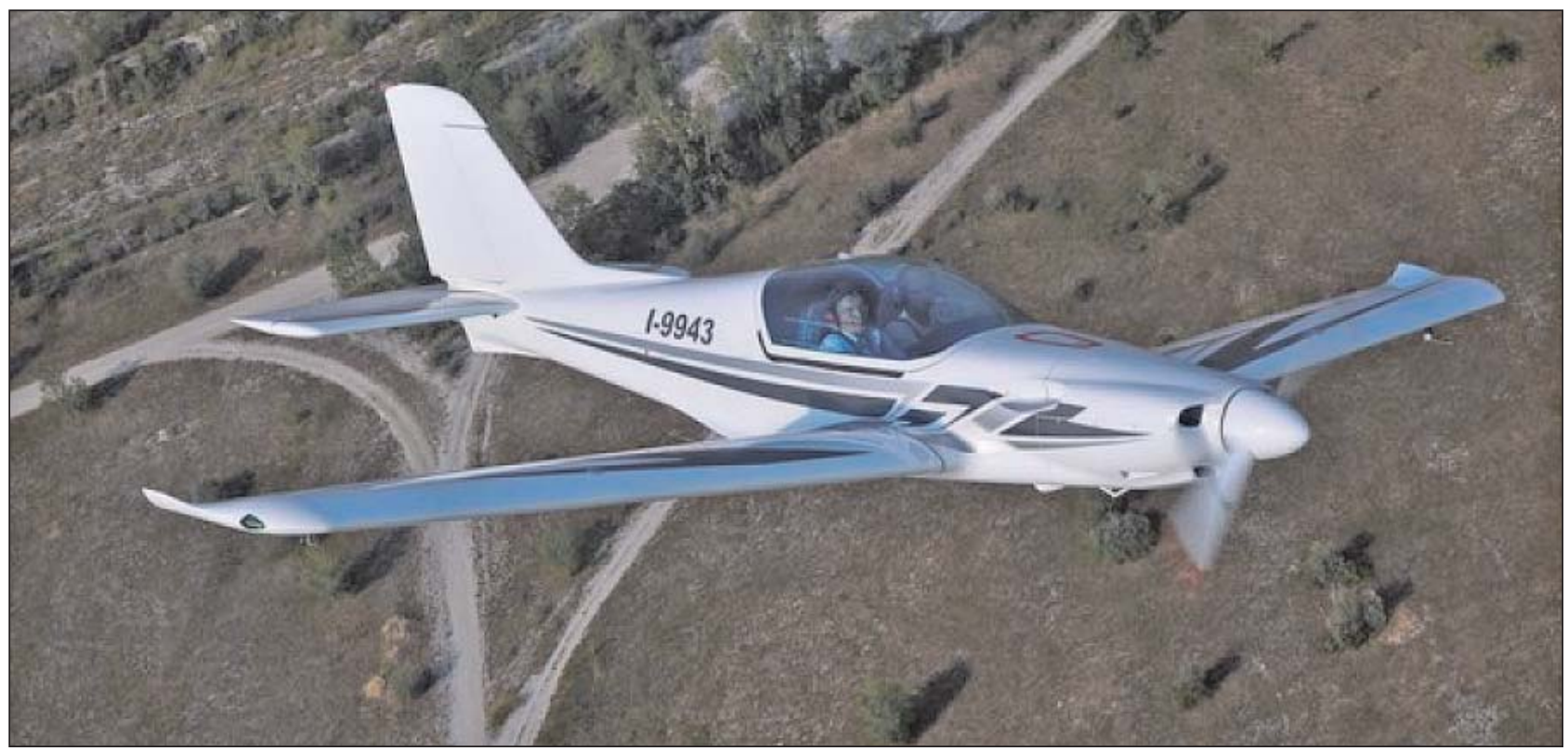

9. ábra. A hazai, behúzható futóművű, kétüléses Corvus Phantom RG már korszerū technológiával készül

motorgyárak a teljes meglévő infrastruktúrával rendelkeznek, a már beépített motorok cseréjére felkészültek. A kerozinnal összehasonlítva a benzin sokkal lobbanékonyabb, a levegőben kigyulladt repülőgép égése kritikusabb. A magasabb tűzbiztonságú kerozin üzemanyag-felhasználás újabb előnyöket hoz, amelynek szomorú aktualitása az a tűzeset, amelynek részben következményeként a Jak-52es típus leváltásra került. Összeségében egy kerozin meghajtású dízelrepülőgép beszerzése számos területen könynyebbséget jelenthet.

Az újonnan megjelent feladatoknak és körülményeknek megfelelően egy hatásfokában kiváló, költségtakarékos rendszer építhető ki a katonai-civil vegyes felhasználású repülőgépek rendszerbe állításával. Könnyű, többfeladatú - kiképző, felderítő, csapásmérő - repülőgép rendszerbe álítása lehet a kívánatos, amely cserélhető konténerrendszerben (pl. felderítő- és célmegjelölő, illetve akár fegyverzeti konténer) képes feladatait ellátni. Egy ilyen légijármű ugyan nem képes a vadászrepülők vagy a helikopterek katonai szerepét átvenni, de azok az új igények mellett számos feladatukat hatékonyabban és gazdaságosabban tudják ellátni.

Ilyen könnyű repülőgép katonai felhasználására, gyártásra és rendszerbe állításra is számos nemzetközi példát látunk. A légi járműveket hazai gyártásban, alacsony költséggel, a feladatra szabva lehetne előállítani. Az Egyesült Államokban indult LAAR program hasonlatos célkitűzésekkel indult, ezért a hazai megvalósításnak is kiváló példája lehet. A hazai ipari háttér ma már képes ezen feladat megoldására. Napjainkban folyamatosan növekvő számban akkreditált, a repülőipar AS/EN 9100-as minőségbiztosítási rendszerének megfelelő hazai cég van jelenleg Magyarországon, amelyek ebbe a programba bevonhatók. A már meglévő ipari háttér akkreditálása ezt a kört jelentősen tovább bővítheti.

A jelentősebb repülőipari kapacitások közül néhány példát is megemlítünk a teljesség igénye nélkül. A Flytech Repüléstechnika Kft. $6700 \mathrm{~m}^{2}$-es gyártócsarnokban, 62 munkatárssal sárkányszerkezeteket gyárt az ultrakönnyű repülőgépek németországi piacán vezető helyen álló Comco lkarus $\mathrm{GmbH}$ és a Diamond számára. (Korábban ők gyártották a Szojka UAV sárkányszerkezetét is. [1]) A Corvus
Aircraft Kft. vákumozott Prepreg Nomex szendvics, illetve kevlár-szén hibrid kompozit technológiával gyárt egy- és kétszemélyes könnyü repülőgépeket. A cég repülőgép mentőernyő beépítésével és robbanásbiztos üzemanyagtartály kifejlesztésével is foglalkozik. Utóbbi előfeltétele lehet a katonai alkalmazásnak is.

Az Audi motorgyártás magyarországi jelenléte, illetve a gyár hazánkban működtetett fejlesztőcsoportja elérhetővé teszi a repülőgép motorjának hazai beszerzését és gépjármüből repülőmotorrá történő átalakítását (duplikált motorvezérlő elektronika stb.). Az Audi gyár V12 TDI turbófeltöltéses dízelmotorja 6,0 liter hengerürtartalmú, 12 hengeres, common-rail befecskendező-rendszerü, 368 kW (500 LE) teljesítményű erőforrás. A motorblokk speciális technológiával öntött alumínium anyaga lehetővé teszi az erőforrás szerkezeti tömegének alacsony szinten tartását, a kedvező $210 \mathrm{gkW} / \mathrm{h}$ fogyasztás további tömegmegtakarítást tesz lehetővé. Nagy teljesítménye és alacsony tömege alkalmas repülőgép-motorrá teszi. Ennek megfelelően repülőgépmotorrá történő alakítása, fejlesztése folyamatban van Németországban. (A hazai résztvételi arány és a motorok gyártása szempontjából fontos hazai tényező e szempontból a Mercedes, Opel és a Suzuki jelenléte is.)

Adott feladatokra optimalizált repülőgép tervezésénél új koncepciót kell megvalósítani. Ebben a kategóriában általában a polgári célú és fejlesztésű gépeket utólag szerelik fel fegyverzettel, és teszik alkalmassá egyes katonai feladatok megoldására. Olyan tervezési irányelveket célszerű követni, ahol alapvetően katonai feladatok megoldását, tulajdonságokat kell megoldani, és emellett kell lehetővé tenni a polgári felhasználás lehetőségét is.

Már 30 repülőgép legyártása esetén kedvezően oszlanak meg, illetve alakulnak a fejlesztés, az engedélyeztetés és a gyártás költségei. Az egyéb igények (katonai, rendőri, mezőgazdasági, utasrepültetési, katasztrófavédelmi, vegyivagy sugárfelderítési) kielégítésével együtt a reálisan tervezett gyártási darabszám 200 feletti. A fent vázolt rendszer felállításához, a vegyes feladatok ellátására olyan könnyű repülőgép volna kívánatos, amely különböző cserélhető, függeszthető, beépíthető konténerrendszerben több feladat ellátására is alkalmas, továbbá alacsony előállítási és fenntartási költségekkel állítható rendszerbe. Maximális 

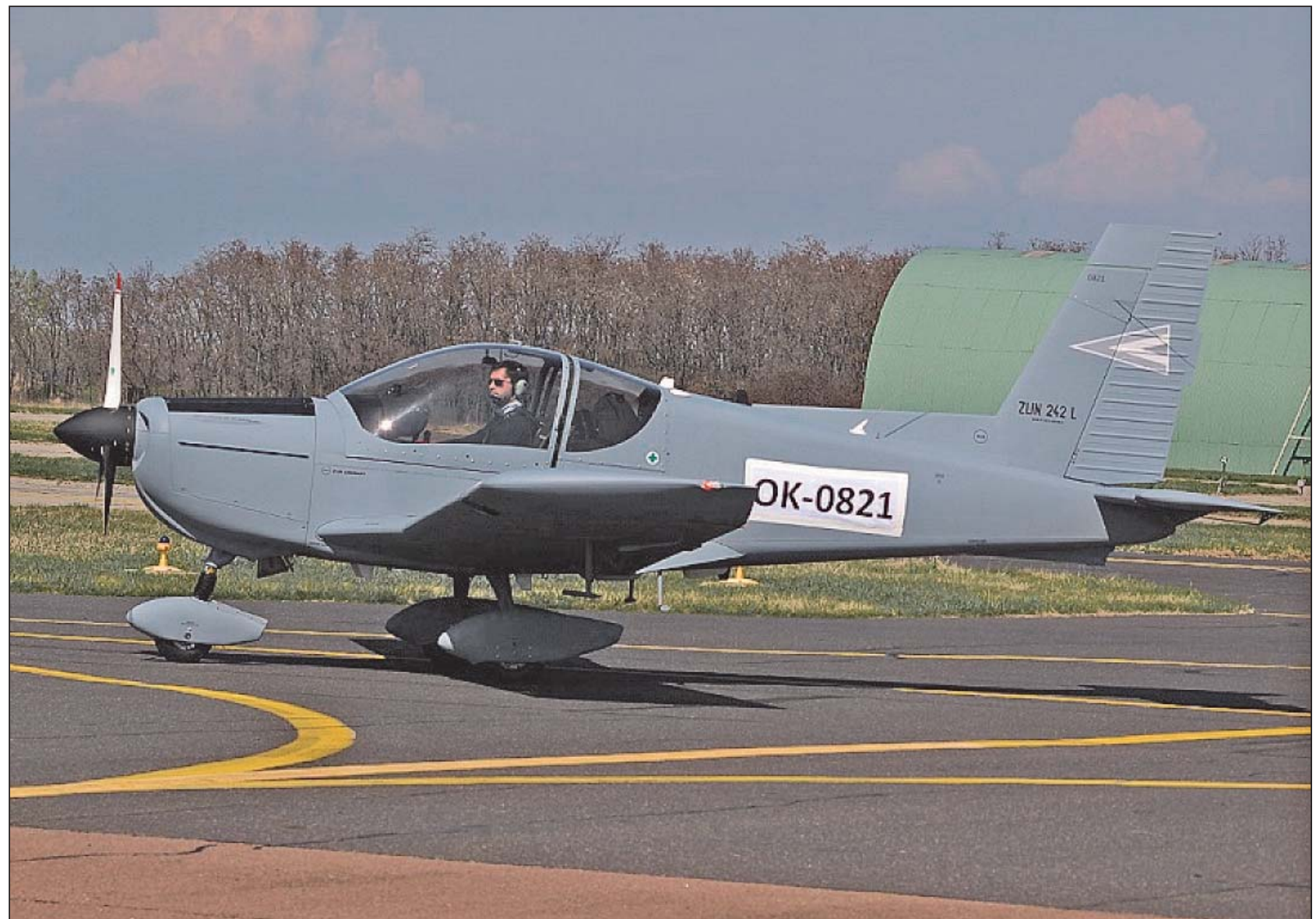

\section{0. ábra. Az új Zlin kiképző repülőgép Szolnokon}

felszálló tömege a 2250 kg-ot nem haladja meg, és emellett $7-800 \mathrm{~kg}$ hasznos terhelhetőségű kell, hogy legyen. Mindenképpen előnyt élvez a NATO egységesített üzemanyag-koncepciójához (SFC - Single Fuel Conception Egységesített Üzemanyag Koncepció) igazodó meghajtás (a kategóriához igazodva dugattyús dízelmotor, esetleg gázturbina) és a tervezésnél minden olyan megoldás, amely a katonai vagy a polgári feladatok ellátását megkönnyíti (pl. alacsony felderíthetőség, zaj, hő, radarkép, autonóm navigáció, illetve a tervezettől jobb paraméterek, illetve egyéb állami érdekeket kielégítő speciális képesség). Hangsúlyozandó, hogy elsődleges szempont a rendszer megvalósítása esetén a hazai iparnak és kutatás-fejlesztésnek a felhasználása. A LAAR program mintája lehet a magyarországi civil-katonai közös felhasználású gép rendszerbe álításának. A program bevezetése katalizátora lehet a magyar repülés fejlesztésének.

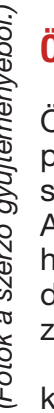

\section{Összegzés}

Összességében elmondható, hogy a beszerzésre került repülőgépek és technikai eszközök jelentős előrelépésnek számítanak a Magyar Honvédségben, a katonai repülésben. Az évek óta szorító eszközhiány a rendszer működési nehézségeit okozta, amely így lélegzetvételhez juthat. A modern technikai eszközök használata, a Zlin típusok műszerezettsége új irányvonalat hozhat a hazai katonai repülésbe.

Olyan oktatási rendszert alapozhat meg, amely a technikai eszközök hiányában az elmúlt években hazánkban nem létezett. Természetesen ezen beszerzés fontos lépés, de csak az első lehet egy megkezdett úton, ahol a repülőgép és helikopter eszközöket pótoljuk, modernizáljuk, a kor követelményinek megfelelővé tesszük. A későbbi fejlesztésekben esetleg a hazai érdekeknek megfelelően önálló fejlesztések is belekerülhetnek.

\section{FORRÁSOK}

[1] Hajdú Ferenc - Sárhidai Gyula: A Magyar Királyi Honvéd Haditechnikai Intézettől a HM Technológiai Hivatalig. Honvédelmi Minisztérium, Budapest, 2005. 188-192. o.

[2] http://www.honvedelem.hu/cikk/62523.

[3] http://www.zlinaircraft.eu/en/.

[4] Single Fuel Conception: STANAG 4362.

[5] Hennel Sándor: Dízelmotorok felhasználhatóságának lehetőségei a katonai repülésben. Honvédségi Szemle, 65.évfolyam 5. sz. 2011. szeptember.

[6] Hennel Sándor: Többfeladatú könnyű repülőgép vegyes katonai-polgári alkalmazásának gazdaságossági vizsgálata. Katonai Logisztika, 2012. 1. sz.

[7] Hajdu Péter: Gerilla Zlin repülőgépek Sri Lanka egén. Haditechnika, 2012. évi 6. sz.

[8] Takács Miklós: A cseh-szlovák repülőipar története I-III. rész. Haditechnika, 2013. évi 4-5-6. sz.

[9] Dieter Thomas: Pilot Report Moravan Zlin Z-242L. Aerokurier, 1994. évi 1. szám 12-19. o. 